\title{
DETERMINANTS OF VITAMIN D STATUS AMONG JORDANIAN EMPLOYEES: FOCUS ON THE NIGHT SHIFT EFFECT
}

\author{
EMAN ALEFISHAT ${ }^{1}$ and RANA ABU FARHA ${ }^{2}$ \\ ${ }^{1}$ The University of Jordan, Amman, Jordan \\ Faculty of Pharmacy, Department of Biopharmaceutics and Clinical Pharmacy \\ ${ }^{2}$ Applied Science Private University, Amman, Jordan \\ Faculty of Pharmacy, Department of Clinical Pharmacy and Therapeutics
}

\begin{abstract}
Objectives: To assess the association between night work and 25-hydroxy vitamin D (25OHD) levels, and to evaluate effect of potential risk factors on 25OHD levels. Material and Methods: A total of 140 adult Jordanian employees were recruited. Demographic, lifestyle and working patterns data were documented through a well-structured questionnaire. Vitamin D status was assessed by measuring circulating concentrations of 25OHD. Results: Mean 25OHD level was $23.8 \mathrm{ng} / \mathrm{ml}$. No significant difference was found in 25OHD levels between the summer and winter $(p=0.46)$, or between males and females $(\mathrm{p}=0.35)$. The female night workers had significantly lower serum 25OHD levels compared to the female day workers $(\mathrm{p}=0.01)$. No significant difference in serum 25OHD levels was found between the night and day male workers $(\mathrm{p}=0.25)$. The number of night shifts/month was negatively correlated with 25OHD levels in both the males and females ( $p=0.01$ and $p=0.007$, respectively). Age was positively correlated with 25OHD levels in both the males and females $(\mathrm{p}=0.02$ and $p=0.001$, respectively). Body mass index was negatively associated with $250 \mathrm{HD}$ levels in the whole sample $(\mathrm{p}=0.03)$, but not within each gender group ( $p=0.21$ for the males and $p=0.09$ for the females). Smoking had no significant association with $25 \mathrm{OHD}$ levels ( $\mathrm{p}=0.99$ for the males and $\mathrm{p}=0.22$ for the females). Conclusions: Our results suggest that women working night shifts are at higher risk of $25 \mathrm{OHD}$ deficiency, and, consequently, of other health problems linked to 25OHD deficiency. Int J Occup Med Environ Health 2016;29(5):859-870
\end{abstract}

Key words:

Vitamin D, Vitamin D deficiency, Night shift work, Jordan, Working conditions, Risk assessment

\section{INTRODUCTION}

Vitamin D, also known as cholecalciferol, is a fat soluble vitamin, which plays a critical role in the maintenance of normal blood levels of calcium and phosphorous [1,2]. It is rapidly metabolized in the liver to form 25-hydroxy vitamin D (25OHD) [3]. Another hydroxylation of $25 \mathrm{OHD}$ takes place in the kidney through the action of 1-alpha hydroxylase enzyme, to yield 1,25-dihydroxy vitamin D (1,25DOHD), which is the most potent vitamin D metabolite [3]. While 1,25DOHD is the most potent vitamin D metabolite, levels of 25OHD reflect the body's vitamin D stores more accurately [4].

A low 25OHD level is a major public health issue, with around one billion people worldwide affected [5]. Workers

This research was sponsored by the Deanship of Scientific Research at The University of Jordan (grant: "Circadian rhythm disruption as a predictor for cardiovascular risk”, No. 68/2013-2014). Principle investigator: Eman Alefishat, Ph.D.

Received: March 31, 2015. Accepted: December 14, 2015.

Corresponding author: E. Alefishat, The University of Jordan, Faculty of Pharmacy, Department of Biopharmaceutics and Clinical Pharmacy, Queen Rania Street, Amman 11942, Jordan (e-mail: e.alefishat@ju.edu.jo). 
with $250 H D$ deficiency often complain of fatigue, myalgia and muscle pain [6]. They reportedly think of these symptoms as a result of their working intensity, and they rarely associate it with $250 \mathrm{OH}$ deficiency [7]. The exact definition of 25OHD deficiency is still controversial. Most agree that $<20 \mathrm{ng} / \mathrm{ml} 25 \mathrm{OHD}$ levels are considered to be deficient, whereas 25OHD levels of 21-29 $\mathrm{ng} / \mathrm{ml}$ are considered to indicate insufficiency, and levels $>30 \mathrm{ng} / \mathrm{ml}$ are considered to be sufficient [5,8-12]. A number of factors have been found to be associated with low 25OHD levels. These factors include, among others, low sun exposure, age, obesity, smoking, dress style in the case of women and physical activity [5,13-20].

In the absence of adequate sun exposure, 25OHD levels may be insufficient to achieve the desired physiologic role [5,21-24]. It is, therefore, anticipated that working at night would affect employees' level of sun exposure, and subsequently, their 25OHD status. Approximately 20\% of working populations in developed countries are night workers [25]. Although the role of such workers, including: workers in healthcare, transportation and other industries, is vital, their working pattern can be associated with various adverse health outcomes, such as: diabetes, metabolic syndrome, cardiovascular diseases and other conditions [26-32].

Several studies have shown that night work is associated with the increasing incidence of different types of cancer, mainly breast cancer [33,34], but still the link between night work and breast cancer is insufficient [35]. It has been suggested that $1,25 \mathrm{DOHD}$ plays a role in the increased risk of cancer associated with night-shift work, where the reduction in melatonin concentrations due to night shift work may reduce ligand-induced transcriptional activity of the vitamin $\mathrm{D}$ receptor (VDR) [36,37]. This reduction in VDR results in suppressing the negative-growth regulation by $1,25 \mathrm{DOHD}$, which may increase cancer incidence [38]. It has been found that 1,25DOHD is associated with reduction in cellular proliferation, and can also suppress cancer growth by induction of apoptosis or inhibition of angiogenesis $[39,40]$.

Also an increased risk of osteoporotic fractures among night workers has been reported. A group in the United States has revealed that night work for more than 20 years is associated with an elevated risk of hip and wrist fractures [27]. Due to 25OHD role in bone health, and its association with the increased risk of osteopenia, osteoporosis, and fractures in adults [5,41,42], this modest effect of night work on fracture risk may suggest a link between night work and 25OHD deficiency.

The direct link between night work and the actual levels of 25OHD have been investigated in a few studies, where it has been found that 25OHD levels were significantly lower in night workers than in day workers [43-46]. The main aim of this study is to assess the association between night work and 25OHD levels among Jordanian workers working in Jordan University Hospital (JUH) and The University of Jordan including: nurses, physicians, pharmacists and security officers. We also aimed at evaluation of the effect of several risk factors on 25OHD status.

\section{MATERIAL AND METHODS}

\section{Study design and data collection}

This is a cross-sectional study that was conducted between June-July (summer), and November-December (winter) 2014. During the study period 160 adult employees, who fulfilled the inclusion criteria, were contacted at Jordan University Hospital and The University of Jordan. Only 140 employees agreed to participate in the study and to provide blood samples (response rate 88\%) (Figure 1). This study was conducted following the guidelines outlined in the Declaration of Helsinki. Verbal consent was obtained from each participant, and an institutional review board committee approval was sought from The University of Jordan. The sample was obtained using a convenient sampling technique. 


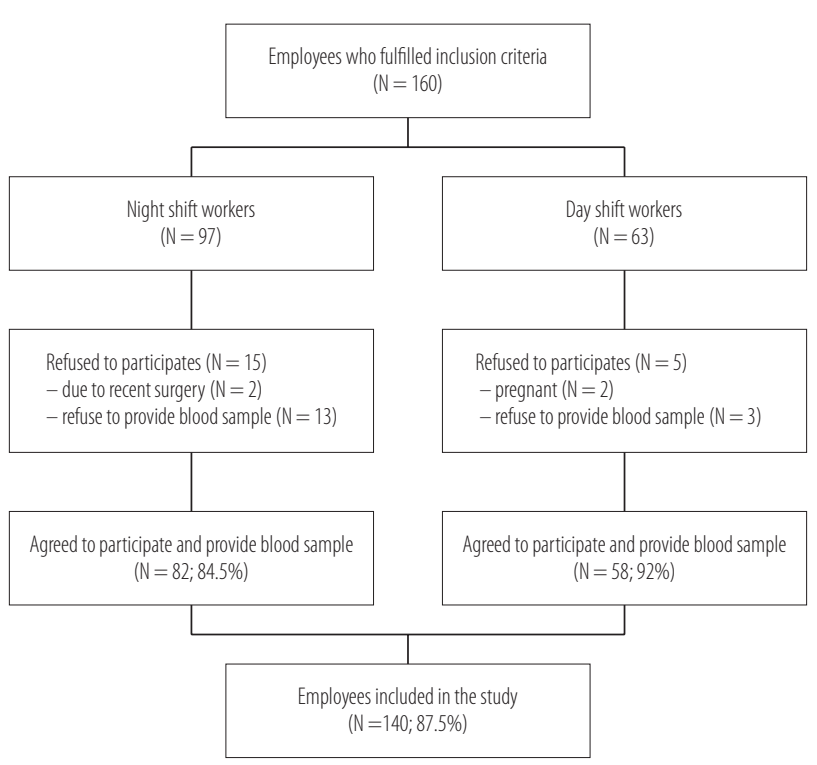

Fig. 1. Employees selection for the study

The study sample was recruited by well-trained assistants. Information regarding demographic data, marital status, educational level, working patterns, smoking habits and the level of any physical activity was obtained using a structured questionnaire. Average numbers of night shift/ month were obtained from the administrative records for all the employees. Then, the participants were categorized into two groups based on their working pattern; day workers (subjects working from 7:00 a.m. till 4:00 p.m. without any shift work), and night workers (subjects working from 4:00 p.m. till 7:00 a.m. at least 4 times per month for at least 3 years). Blood samples were collected from all the participants for the purpose of $25 \mathrm{OHD}$ measurement.

\section{Serum 250HD measurement}

Blood samples $(5 \mathrm{ml})$ for $25 \mathrm{OHD}$ measurement were drawn from the brachial vein from all the participants. The samples were allowed to clot for $2 \mathrm{~h}$ at room temperature, and then the serum was separated by centrifugation at a speed of 4000 rotations per minute (rpm) for $10 \mathrm{~min}$ and divided into aliquot of $1 \mathrm{ml}$. Aliquots were frozen at $-80^{\circ} \mathrm{C}$ until $25 \mathrm{OHD}$ analysis was performed.
The serum samples were thawed in a dry bath at $37^{\circ} \mathrm{C}$ immediately prior to the analysis. Then a 25OHD level in each sample was measured using the automated immunoassay technique (AIA-1800 analyzer, Tosoh, Japan). Each patient was given a sample cup number and the result was printed referring to each sample cup number; the level of $25 \mathrm{OHD}$ was expressed in $\mathrm{ng} / \mathrm{ml}$. For the levels and results that were lesser than functional sensitivity, the results were reported and printed as $<4 \mathrm{ng} / \mathrm{ml}$.

\section{Statistical analysis}

All the data were entered and analyzed using SPSS 19 (SPSS, Inc., USA). Categorical variables were expressed as frequencies and percentages, and continuous variables were presented as means \pm standard deviation $(\mathrm{M} \pm \mathrm{SD})$. Since the data were normally distributed as evident by their skewness, kurtosis, histogram and the normal probability-probability plot (P-P plot), the independent sample t-test was used to investigate any differences in 25OHD levels among the day and night workers. The $\mathrm{Chi}^{2}$ analysis was used to analyze categorical independent variables.

A simple linear regression was used to identify any factors that may significantly affect 250HD levels among the study participants. Checking for outliers, normality, linearity was performed by means of the methods described by Tabachnick and Fidell (2013) [47]. For all statistical analyses, a p-value of $<0.05$ was considered statistically significant. All the tests were two-tailed.

Due to occupational gender segregation reported in the literature, all the analyses were conducted stratified by gender [48].

\section{RESULTS}

One hundred forty Jordanian employees were recruited in this study, from whom 82 were classified as night workers and 58 as day workers. Fifty-seven percent of the sample 
Table 1. Demographic and clinical characteristics of the study group

\begin{tabular}{|c|c|c|c|}
\hline \multirow[b]{2}{*}{ Variable } & \multicolumn{3}{|c|}{ Respondents } \\
\hline & $\begin{array}{c}\text { males } \\
(\mathrm{N}=60)\end{array}$ & $\begin{array}{l}\text { females } \\
(\mathrm{N}=80)\end{array}$ & $\begin{array}{c}\text { total } \\
(\mathrm{N}=140)\end{array}$ \\
\hline Age [years] $(\mathrm{M} \pm \mathrm{SD})$ & $36 \pm 9$ & $32 \pm 6$ & $34 \pm 8$ \\
\hline \multicolumn{4}{|l|}{ Occupation [n (\%)] } \\
\hline medical field & $33(55)$ & $66(82)$ & $99(71)$ \\
\hline other & $27(45)$ & $14(18)$ & $41(29)$ \\
\hline \multicolumn{4}{|l|}{ Working pattern $[\mathrm{n}(\%)]$} \\
\hline night workers & $47(78)$ & $35(44)$ & $82(58)$ \\
\hline day workers & $13(22)$ & $45(56)$ & $58(41)$ \\
\hline \multicolumn{4}{|l|}{ Educational levels [n (\%)] } \\
\hline primary & $1(1)$ & $1(1)$ & $2(1)$ \\
\hline secondary & $28(47)$ & $32(40)$ & $60(43)$ \\
\hline BSc & $28(47)$ & $34(55)$ & $72(51)$ \\
\hline MSc & $3(5)$ & $3(4)$ & $6(4)$ \\
\hline \multicolumn{4}{|l|}{ Marital status [n (\%)] } \\
\hline single & $12(21)$ & $21(27)$ & $32(24)$ \\
\hline married & $26(79)$ & $57(72)$ & $100(75)$ \\
\hline divorced & $0(0)$ & $1(1)$ & $1(1)$ \\
\hline \multicolumn{4}{|l|}{ Active smoking [n (\%)] } \\
\hline yes & $28(47)$ & $6(8)$ & $34(24)$ \\
\hline no & $32(53)$ & $74(92)$ & $106(76)$ \\
\hline \multicolumn{4}{|l|}{ Exercises* $[\mathrm{n}(\%)]$} \\
\hline yes & $28(47)$ & $19(24)$ & $47(34)$ \\
\hline no & $32(53)$ & $61(76)$ & $93(66)$ \\
\hline $25 \mathrm{OHD}[\mathrm{ng} / \mathrm{ml}](\mathrm{M} \pm \mathrm{SD})$ & $23 \pm 10$ & $25 \pm 15$ & $24 \pm 13$ \\
\hline \multicolumn{4}{|l|}{$25 \mathrm{OHD}$ category $[\mathrm{n}(\%)]$} \\
\hline deficient $(\leq 20 \mathrm{ng} / \mathrm{ml})$ & $30(50)$ & $37(46)$ & $67(48)$ \\
\hline insufficient (21-29 ng/ml) & $19(32)$ & $15(19)$ & $34(24)$ \\
\hline sufficient ( $\geq 30 \mathrm{ng} / \mathrm{ml}$ ) & $11(18)$ & $28(35)$ & $39(28)$ \\
\hline
\end{tabular}

M - mean; SD - standard deviation; BSc - bachelor of science; MSc - master of science; 25OHD - 25-hydroxy vitamin D.

* Exercise status is only considered positive in the subjects doing physical activity of any kind for at least 30 min per day, 3 times weekly.

were females; the mean age of the subjects was 34 years. Seventy-five percent of the studied sample were married and around 24\% were smokers. Table 1 summarizes demographic characteristics of the sample as a whole and for each gender.
Mean 25OHD level among the study sample was $24 \mathrm{ng} / \mathrm{ml}$. Forty-seven percent of the study subjects was found to have $25 \mathrm{OHD}$ deficiency, with levels $\leq 20 \mathrm{ng} / \mathrm{ml}$, and around 24\% had insufficient 25OHD levels (21-29 ng/ml) (Table 1). It was found that 25OHD levels 
were not significantly different between the males and females; mean $25 \mathrm{OHD}$ levels were $23 \mathrm{ng} / \mathrm{ml}$ and $25 \mathrm{ng} / \mathrm{ml}$, respectively $(p=0.35)$. No significant difference was found in 25OHD levels between the summer and winter; mean $250 \mathrm{HD}$ levels were $24 \mathrm{ng} / \mathrm{ml}$ and $22 \mathrm{ng} / \mathrm{ml}$, respectively $(\mathrm{p}=0.46)$.

Table 2 shows 25OHD profile among the study sample based on a working pattern. The night workers had significantly lower mean 25OHD levels $(21 \mathrm{ng} / \mathrm{ml})$ compared to the day workers $(28 \mathrm{ng} / \mathrm{ml})(\mathrm{p}=0.003)$, with over half of them $(55 \%)$ having deficient levels of 25OHD compared to $38 \%$ within the day work group. This effect was significant both in the winter and in the summer.

The simple linear regression was used to identify any factors that may significantly affect $25 \mathrm{OHD}$ levels among the study participants (Table 3). The effect of age, night work, number of night shift/month, exercise, smoking and body mass index (BMI) on 25OHD levels was investigated. The female night workers had significantly lower 25OHD levels compared to the day workers $(p=0.01)$. On the contrary, there was no significant difference in 25OHD levels between the male night and the day workers $(p=0.25)$. The number of night shifts/month was negatively correlated with $25 \mathrm{OHD}$ levels in both the males and females ( $p=0.01$ and $p=0.007$, respectively), while age was positively correlated with $25 \mathrm{OHD}$ levels $(\mathrm{p}=0.02$ and $\mathrm{p}=0.001$, respectively).

Although the results showed no association between BMI and 25OHD levels within each gender group ( $p=0.21$ for males and $p=0.09$ for females), this association existed in the sample as a whole, where a significant negative correlation between obesity and 25OHD levels was found $(\mathrm{p}=0.03)$. Physical activity was shown to be negatively associated with 25OHD levels in the males $(p=0.03)$, but not in the females $(p=0.42)$. Smoking had no significant association with $25 \mathrm{OHD}$ levels $(\mathrm{p}=0.99$ for the males and $\mathrm{p}=0.22$ for the females) (Table 3 ).

Table 2. 25-Hydroxy vitamin D (25OHD) profile among the study group based on a working pattern

\begin{tabular}{|c|c|c|c|c|}
\hline \multirow[b]{2}{*}{ Variable } & \multicolumn{3}{|c|}{ Work time } & \multirow[b]{2}{*}{$\mathrm{p}$} \\
\hline & $\begin{array}{c}\text { day } \\
(\mathrm{N}=58)\end{array}$ & $\begin{array}{c}\text { night } \\
(\mathrm{N}=82)\end{array}$ & $\begin{array}{c}\text { total } \\
(\mathrm{N}=140)\end{array}$ & \\
\hline $25 \mathrm{OHD}[\mathrm{ng} / \mathrm{ml}](\mathrm{M} \pm \mathrm{SD})^{\mathrm{a}}$ & $28 \pm 14$ & $21 \pm 12$ & $24 \pm 13$ & $0.003^{*}$ \\
\hline \multicolumn{5}{|l|}{$25 \mathrm{OHD}$ category $[\mathrm{n}(\%)]^{\mathrm{b}}$} \\
\hline deficient $(\leq 20 \mathrm{ng} / \mathrm{ml})$ & $22(38)$ & $45(55)$ & $67(48)$ & $0.001^{*}$ \\
\hline insufficient $(21-29 \mathrm{ng} / \mathrm{ml})$ & $10(17)$ & $24(40)$ & $34(24)$ & \\
\hline sufficient $(\geq 30 \mathrm{ng} / \mathrm{ml})$ & $26(45)$ & $13(16)$ & $39(28)$ & \\
\hline \multicolumn{5}{|l|}{ Gender $(\mathrm{M} \pm \mathrm{SD})^{\mathrm{a}}$} \\
\hline male & $26 \pm 13$ & $22 \pm 10$ & $23 \pm 10$ & 0.250 \\
\hline female & $29 \pm 14$ & $20 \pm 15$ & $25 \pm 15$ & $0.010^{*}$ \\
\hline \multicolumn{5}{|l|}{ Season $(\mathrm{M} \pm \mathrm{SD})^{\mathrm{a}}$} \\
\hline summer & $28 \pm 15$ & $21 \pm 13$ & $24 \pm 14$ & $0.010^{*}$ \\
\hline winter & $28 \pm 10$ & $18 \pm 4$ & $22 \pm 9$ & $0.020^{*}$ \\
\hline
\end{tabular}

Abbreviations as in Table 1.

${ }^{a}$ Using independent sample t-test.

${ }^{\mathrm{b}}$ Using Chi ${ }^{2}$ test.

* Significant at 0.05 significance level. 
Table 3. Simple linear regression analysis for factors affecting 25-hydroxy vitamin D (25OHD) levels in the study group

\begin{tabular}{|c|c|c|c|c|c|c|}
\hline \multirow{3}{*}{ Parameter } & \multicolumn{6}{|c|}{$25 \mathrm{OHD}$ in blood } \\
\hline & \multicolumn{2}{|c|}{$\begin{array}{c}\text { total } \\
(\mathrm{N}=140)\end{array}$} & \multicolumn{2}{|c|}{$\begin{array}{c}\text { females } \\
(\mathrm{N}=80)\end{array}$} & \multicolumn{2}{|c|}{$\begin{array}{c}\text { males } \\
(\mathrm{N}=60)\end{array}$} \\
\hline & $\beta^{* *}$ & $\mathrm{p}$ & $\beta^{* *}$ & $\mathrm{p}$ & $\beta^{* *}$ & $\mathrm{p}$ \\
\hline Age & 0.28 & $0.001^{*}$ & 0.37 & $0.001^{*}$ & 0.280 & $0.02 *$ \\
\hline Working pattern ( 1 - day workers, 2 - night workers) & -0.25 & $0.003^{*}$ & -0.28 & $0.010^{*}$ & -0.150 & 0.25 \\
\hline Night shifts/month & -0.29 & $0.000^{*}$ & -0.30 & $0.007^{*}$ & -0.300 & $0.01^{*}$ \\
\hline Exercises $(1-$ yes, 2 - no $)$ & 0.06 & 0.450 & -0.09 & 0.420 & 0.280 & $0.03^{*}$ \\
\hline Active smoking $(1-$ yes, $2-$ no $)$ & 0.09 & 0.290 & 0.13 & 0.220 & 0.001 & 0.99 \\
\hline Body mass index (BMI) & -0.17 & $0.030^{*}$ & -0.19 & 0.090 & -0.160 & 0.21 \\
\hline
\end{tabular}

$\beta$ - standardized beta coefficient.

* Significant at 0.05 significance level.

** When $\beta$ is positive this means that there is direct relationship between $25 \mathrm{OHD}$ level and independent variable, while negative $\beta$ means that there is inverse relationship between $25 \mathrm{OHD}$ level and independent variable.

\section{DISCUSSION}

The main aim of this study was to investigate the association between working patterns and 250HD levels among Jordanian workers. The effect of other factors was also investigated. Our study sample presented a mean serum 25OHD level of $24 \mathrm{ng} / \mathrm{ml}$ (standard deviation $(\mathrm{SD})=13$ ), indicating insufficient $25 \mathrm{OHD}$ levels. The literature has reported a wide variation across studies assessing mean 250HD levels among different populations. A systematic review involving 195 studies conducted in 44 countries, has found that the mean population-level of $25 \mathrm{OHD}$ ranges $1.96-54.5 \mathrm{ng} / \mathrm{ml}$, with $88 \%$ of the studies reporting inadequate mean values $<30 \mathrm{ng} / \mathrm{ml}$ [49].

In our sample, no significant difference was found in 25OHD levels between the summer and winter; mean 25OHD levels were $24 \mathrm{ng} / \mathrm{ml}(\mathrm{SD}=14)$ and $22 \mathrm{ng} / \mathrm{ml}(\mathrm{SD}=9)$, respectively. This finding was inconsistent with previous findings that individuals could have adequate 25OHD levels in the summer months but suboptimal levels in the winter [50,51]. Since the latitude of Amman (Jordan) is $31^{\circ} \mathrm{N}$, cutaneous 25OHD synthesis is almost similar all year round, which can explain lack of significant difference in 250HD levels between the summer and winter in our results [52].

The association between 25OHD levels and gender is controversial. A previous study from Jordan has shown that the prevalence of low $25 \mathrm{OHD}$ status $(25 \mathrm{OHD}<30 \mathrm{ng} / \mathrm{ml})$ was $37 \%$ in females compared to $5 \%$ in males. Dress style in the case of females was independently affecting 25OHD status; where women wearing hijab or niqab were at higher risk of low 250HD levels than those dressed as western women [20]. Despite this finding, our results showed no significant difference in 25OHD levels between the males and females; mean 25OHD levels were $23 \mathrm{ng} / \mathrm{ml}(\mathrm{SD}=10)$ and $25 \mathrm{ng} / \mathrm{ml}(\mathrm{SD}=15)$ in the males and females, respectively. Hyppönen et al. have reported, in a nationwide study, that in British adults the association between gender and 25OHD levels depended on the month of measurement, showing lower 25OHD levels in females only during the summer and fall. They have concluded that no consistent monthly sex differences were apparent during the winter and spring [53]. A study from Brazil has revealed no significant gender related differences in mean serum 25OHD among the study sample [54]. On the other hand, reports from China 
and Japan have shown that 25OHD deficiency is largely attributed to female sex [18,55].

The overall night workers had significantly lower mean $25 \mathrm{OHD}$ levels $(21 \mathrm{ng} / \mathrm{ml}, \mathrm{SD}=12)$ compared to the day workers $(28 \mathrm{ng} / \mathrm{ml}, \mathrm{SD}=14)$. This effect was significant both in the winter and summer. However, no significant difference in serum 25OHD levels was found between the night and day male workers, while the female night workers had lower serum 25OHD levels compared to the female day workers. This result was consistent with previous findings [43-46]. Ward et al. have reported that night work was associated with low 250HD levels in females but not in males [43]. In addition, Olivieri et al. and Romano et al. have found that significantly low 25OHD levels were shown in night workers compared to day workers $[44,46]$. On the other hand, a Korean study has shown that male, but not female, night workers had significantly lower 25OHD levels compared to day male workers [45].

Maeda et al. have explored the relationship between 25OHD levels and sun exposure, they collected blood samples once at two different times in the winter and summer from participants with different occupations [54]. This group have noticed that physicians, who chiefly worked at night, presented significantly lower 250HD levels than other investigated workers. However, this was significant only in winter, which they have interpreted as a result of more intense solar exposure, which corrected 25OHD levels in the summer when the difference disappeared.

In addition, in a case report, Plehwe and Carey have reported a patient who experienced continuous night work for 10 years with minimal sunlight exposure. He had profound 25OHD deficiency; 25OHD level was $<12 \mathrm{nmol} / \mathrm{l}$ $(<4.8 \mathrm{ng} / \mathrm{ml})$. They referred this deficiency to multiple risk factors for 25OHD deficiency in this patient, which among others included night work (pigmented skin, habitual and vegetarian diet) [24].
A higher risk of 250HD deficiency in subjects working at night can be a result of the reduced solar ultraviolet B (UVB) irradiance due to daytime sleeping as described by the literature $[53,56]$. It is recommended that the maximum daily $25 \mathrm{OHD}$ levels are achievable through casual midday/lunch hour sun exposure [17]. Due to their working hours and daytime sleeping, most night workers do not get exposed to adequate sunlight during this time of the day, and as a result they may be at higher risk of developing $25 \mathrm{OHD}$ deficiency. In our study, the number of night shift/month was associated with lower 25OHD levels. This result was expected, since the workers with higher number of nights/month have lower duration of sun exposure.

We investigated the effect of some risk factors on 25OHD levels. Our results showed a positive correlation between age and serum 25OHD levels for both the males and females. Age was shown to be positively associated with $25 \mathrm{OHD}$ levels in previous reports [15,55]. Lower serum 25OHD levels in younger individuals has been suggested to be associated with their lower forearm bone mineral content [15]. On the contrary, other studies have shown higher 250HD levels in younger individuals $[57,58]$.

The present study showed that higher BMI is associated with lower basal 25OHD in the sample as a whole. This is consistent with the reported in the literature negative association between 25OHD levels and obesity [59-66]. This effect was not evident for each gender group; this may be due to a small sample size in each group. Although the mechanism underlying an increased risk of $25 \mathrm{OHD}$ deficiency in obesity is uncertain, it has been suggested that the metabolic clearance of $25 \mathrm{OHD}$ levels may increase in obesity. This clearance has been suggested to be through enhanced uptake by adipose tissue [67], which results in lower bioavailability of $25 \mathrm{OHD}$ from cutaneous and dietary sources due to its deposition in body fat compartments [59]. Other study has suggested that 
low 25OHD levels in obese patients can be explained by the dilution of $25 \mathrm{OHD}$ in the large fat mass of those individuals [66].

Physical activity had no significant correlation with serum 250HD levels for the sample as a whole; however, the males with a sedentary lifestyle showed significantly higher serum $25 \mathrm{OHD}$ levels. No significant association was detected in the female workers. This result was inconsistent with a previous study; which has shown that $25 \mathrm{OHD}$ deficiency is attributed to a sedentary lifestyle [13].

Smoking had no significant correlation with serum 25OHD levels in both the males and females. Our results were in agreement with a previous study that has shown no correlation between smoking and 250HD levels [45]. On the other hand, other studies have shown a significant correlation between 25OHD deficiency and smoking $[18,68]$. The relatively small prevalence of smokers among our sample, along with the small sample size might be attributed to the lack of statistical power to detect any association between smoking and 25OHD levels.

Finally, since low 25OHD status is associated with an increased risk of different diseases [5,33,34,41,42], 250HD supplementation to night workers has been suggested to prevent such diseases and to improve their health status [39]. However, health effects of long term exposure to high levels of 25OHD are largely unknown, which necessitates appropriate monitoring while providing such supplements. It is also recommended to encourage this category of workers to have more adequate sun exposure.

It is worth mentioning, that we are aware of some methodological weaknesses of our study, especially the relatively small sample size of the study participants. The strict inclusion criteria of the night workers, where they had to be working from 9:00 p.m. till 7:00 a.m. at least 4 times per month, for at least 3 years, resulted in a limited number of individuals meeting the inclusion criteria.

\section{CONCLUSIONS}

In conclusion, our results showed that there is a negative association between 25OHD levels and night working in females, but not in males. Higher numbers of night shifts/month were associated with lower 25OHD levels. Reduced solar UVB irradiance due to daytime sleeping can be one of the major causes of lower 25OHD levels in night workers. The imminent link between 25OHD levels and cancer, diabetes, obesity, cardiovascular diseases and other health problems, highlights the need for educational programs targeting high risk groups, including night workers. Supplements of $25 \mathrm{OHD}$ can be of benefit to these high risk groups.

\section{REFERENCES}

1. Abrams SA, Griffin IJ, Hawthorne KM, Gunn SK, Gundberg CM, Carpenter TO. Relationships among vitamin D levels, parathyroid hormone, and calcium absorption in young adolescents. J Clin Endocrinol Metab. 2005;90(10):5576-81, http://dx.doi.org/10.1210/jc.2005-1021.

2. Kulie T, Groff A, Redmer J, Hounshell J, Schrager S. Vitamin D: An evidence-based review. J Am Board Fam Med. 2009;22(6):698-706, http://dx.doi.org/10.3122/jabfm. 2009.06.090037.

3. Christakos S, Ajibade D, Dhawan P, Fechner A, Mady L. Vitamin D: Metabolism. Rheum Dis Clin North Am. 2012;38(1):1-11, http://dx.doi.org/10.1016/j.rdc.2012.03.003.

4. Kennel KA, Drake MT, Hurley DL. Vitamin D deficiency in adults: When to test and how to treat. Mayo Clin Proc. 2010;85(8):752-7, http://dx.doi.org/10.4065/mcp. 2010.0138 .

5. Holick MF. Vitamin D deficiency. N Engl J Med. 2007; 357(3):266-81, http://dx.doi.org/10.1056/NEJMra070553.

6. Tague SE, Clarke GL, Winter MK, McCarson KE, Wright DE, Smith PG. Vitamin D deficiency promotes skeletal muscle hypersensitivity and sensory hyperinnervation. J Neurosci. 2011;31(39):13728-38, http://dx.doi.org/10.1523/JNEUROSCI.3637-11.2011. 
7. Al Bathi B, Al Zayed K, Al Qenai M, Makboul G, El-Shazly M. Knowledge, attitude and practice of patients attending primary care centers toward vitamin D in Kuwait. Alexandria J Med. 2012;48(3):277-82, http://dx.doi.org/10.1016/ j.ajme.2012.02.003.

8. Chapuy MC, Schott AM, Garnero P, Hans D, Delmas PD, Meunier PJ. Healthy elderly French women living at home have secondary hyperparathyroidism and high bone turnover in winter. EPIDOS Study Group. J Clin Endocrinol Metab. 1996;81(3):1129-33, http://dx.doi.org/10.1210/ jcem.81.3.8772587.

9. Dawson-Hughes B, Heaney RP, Holick MF, Lips P, Meunier PJ, Vieth R. Estimates of optimal vitamin D status. Osteoporos Int. 2005;16(7):713-6, http://dx.doi.org/10.1007/ s00198-005-1867-7.

10. Malabanan A, Veronikis IE, Holick MF. Redefining vitamin D insufficiency. Lancet. 1998;351(9105):805-6, http:// dx.doi.org/10.1016/S0140-6736(05)78933-9.

11. Holick MF, Siris ES, Binkley N, Beard MK, Khan A, Katzer JT, et al. Prevalence of vitamin D inadequacy among postmenopausal North American women receiving osteoporosis therapy. J Clin Endocrinol Metab. 2005;90(6):3215-24, http://dx.doi.org/10.1210/jc.2004-2364.

12. Thomas MK, Lloyd-Jones DM, Thadhani RI, Shaw AC, Deraska DJ, Kitch BT, et al. Hypovitaminosis D in medical inpatients. N Engl J Med. 1998;338(12):777-83, http://dx.doi. org/10.1056/nejm199803193381201.

13. Ardawi MS, Sibiany AM, Bakhsh TM, Qari MH, Maimani AA. High prevalence of vitamin D deficiency among healthy Saudi Arabian men: Relationship to bone mineral density, parathyroid hormone, bone turnover markers, and lifestyle factors. Osteoporos Int. 2012;23(2):675-86, http://dx.doi.org/10.1007/s00198-011-1606-1.

14. Blum M, Dolnikowski G, Seyoum E, Harris SS, Booth SL, Peterson J, et al. Vitamin $\mathrm{D}_{3}$ in fat tissue. Endocrine. 2008; 33(1):90-4, http://dx.doi.org/10.1007/s12020-008-9051-4.

15. Nakamura K, Nashimoto M, Matsuyama S, Yamamoto M. Low serum concentrations of 25-hydroxyvitamin D in young adult Japanese women: A cross sectional study. Nutrition. 2001;17(11-12):921-5, http://dx.doi.org/10.1016/S0899-9007 (01)00662-1.

16. Tsiaras WG, Weinstock MA. Factors influencing vitamin D status. Acta Derm Venereol. 2011;91(2):115-24, http://dx. doi.org/10.2340/00015555-0980.

17. Webb AR, Engelsen O. Ultraviolet exposure scenarios: Risks of erythema from recommendations on cutaneous vitamin D synthesis. Adv Exp Med Biol. 2014;810:406-22, http://dx.doi.org/10.1007/978-0-387-77574-6_6.

18. Zhen D, Liu L, Guan C, Zhao N, Tang X. High prevalence of vitamin $\mathrm{D}$ deficiency among middle-aged and elderly individuals in northwestern China: Its relationship to osteoporosis and lifestyle factors. Bone. 2015;71:1-6, http://dx.doi. org/10.1016/j.bone.2014.09.024.

19. Gerdhem P, Ringsberg KA, Obrant KJ, Akesson K. Association between 25-hydroxy vitamin D levels, physical activity, muscle strength and fractures in the prospective population-based OPRA Study of Elderly Women. Osteoporos Int. 2005;16(11):1425-31, http://dx.doi.org/10.1007/s00198005-1860-1.

20. Batieha A, Khader Y, Jaddou H, Hyassat D, Batieha Z, Khateeb M, et al. Vitamin D status in Jordan: Dress style and gender discrepancies. Ann Nutr Metab. 2011;58(1):10-8, http://dx.doi.org/10.1159/000323097.

21. Chen TC, Chimeh F, Lu Z, Mathieu J, Person KS, Zhang A, et al. Factors that influence the cutaneous synthesis and dietary sources of vitamin D. Arch Biochem Biophys. 2007;460(2):213-7, http://dx.doi.org/10.1016/j.abb. 2006.12.017.

22. Holick MF. Vitamin D. A millenium perspective. J Cell Biochem. 2003;88(2):296-307, http://dx.doi.org/10.1002/ jcb.10338.

23. Holick MF. Resurrection of vitamin D deficiency and rickets. J Clin Invest. 2006;116(8):2062-72, http://dx.doi.org/10.1172/ jci29449.

24. Plehwe WE, Carey RP. Spinal surgery and severe vitamin D deficiency. Med J Aust. 2002;176(9):438-9. 
25. Harma M. Shift work among women - A century-old health issue in occupational health. Scand J Work Environ Health. 2008;34(1):1-3, http://dx.doi.org/10.5271/sjweh.1188.

26. Arendt J. Melatonin and human rhythms. Chronobiol Int. 2006;23(1-2):21-37, http://dx.doi.org/10.1080/ 07420520500464361.

27. Feskanich D, Hankinson SE, Schernhammer ES. Nightshift work and fracture risk: The Nurses' Health Study. Osteoporos Int. 2009;20(4):537-42, http://dx.doi.org/10.1007/s00198008-0729-5.

28. Boggild H, Knutsson A. Shift work, risk factors and cardiovascular disease. Scand J Work Environ Health. 1999;25(2):85-99, http://dx.doi.org/10.5271/sjweh.410.

29. Thomas C, Power C. Shift work and risk factors for cardiovascular disease: A study at age 45 years in the 1958 British birth cohort. Eur J Epidemiol. 2010;25(5):305-14, http:// dx.doi.org/10.1007/s10654-010-9438-4.

30. Costa G, Haus E, Stevens R. Shift work and cancer - Considerations on rationale, mechanisms, and epidemiology. Scand J Work Environ Health. 2010;36(2):163-79, http:/ dx.doi.org/10.5271/sjweh.2899.

31. Grant WB. Ecological studies of the UVB-vitamin D-cancer hypothesis. Anticancer Res. 2012;32(1):223-36.

32. Grant WB. Low vitamin D concentrations may contribute to the increased risk of diabetes mellitus related to shift work. Occup Environ Med. 2015;72(2):161, http://dx.doi. org/10.1136/oemed-2014-102578.

33. Brudnowska J, Pepłońska P. [Night shift work and cancer risk: A literature review]. Med Pr. 2011;62(3):323-38. Polish.

34. Hansen J. Light at night, shiftwork, and breast cancer risk. J Natl Cancer Inst. 2001;93(20):1513-5, http://dx.doi. org/10.1093/jnci/93.20.1513.

35. Ijaz S, Verbeek J, Seidler A, Lindbohm ML, Ojajärvi A, Orsini N, et al. Night-shift work and breast cancer - A systematic review and meta-analysis. Scand J Work Environ Health. 2013;39(5):431-47, http://dx.doi.org/10.5271/sjweh.3371.

36. Hill SM, Blask DE, Xiang S, Yuan L, Mao L, Dauchy RT, et al. Melatonin and associated signaling pathways that control normal breast epithelium and breast cancer. J Mammary Gland Biol Neoplasia. 2011;16(3):235-45, http://dx. doi.org/10.1007/s10911-011-9222-4.

37. Blask DE, Hill SM, Dauch RT, Xiang S, Yuan L, Duplessis T, et al. Circadian regulation of molecular, dietary, and metabolic signaling mechanisms of human breast cancer growth by the nocturnal melatonin signal and the consequences of its disruption by light at night. J Pineal Res. 2011;51(3): 259-69, http://dx.doi.org/10.1111/j.1600-079X.2011.00888.x.

38. Welsh J, Wietzke JA, Zinser GM, Byrne B, Smith K, Narvaez CJ. Vitamin D-3 receptor as a target for breast cancer prevention. J Nutr. 2003;133(7):2425S-33S.

39. Grant WB. A critical review of vitamin D and cancer: A report of the IARC Working Group on vitamin D. Dermatoendocrinol. 2009;1(1):25-33, http://dx.doi.org/10.4161/derm.1.1.7729.

40. Doré JF, Chignol MC. Vitamin D and cancer. Oilseeds Fats Crops Lipids. 2014;21(3):D306, http://dx.doi.org/10.1051/ ocl $/ 2013058$.

41. Bakhtiyarova S, Lesnyak O, Kyznesova N, Blankenstein MA, Lips P. Vitamin D status among patients with hip fracture and elderly control subjects in Yekaterinburg, Russia. Osteoporos Int. 2006;17(3):441-6, http://dx.doi.org/10.1007/ s00198-005-0006-9.

42. Larsen ER, Mosekilde L, Foldspang A. Vitamin D and calcium supplementation prevents osteoporotic fractures in elderly community dwelling residents: A pragmatic population-based 3-year intervention study. J Bone Miner Res. 2004;19(3):370-8, http://dx.doi.org/10.1359/jbmr.0301240.

43. Ward M, Berry DJ, Power C, Hypponen E. Working patterns and vitamin D status in mid-life: A cross-sectional study of the 1958 British birth cohort. Occup Environ Med. 2011;68(12):902-7, http://dx.doi.org/10.1136/oem. 2010.063479 .

44. Olivieri M, Biscardo CA, Valenza D, Verlato G. Night shift, vitamin D and occupational allergies in bakers. Eur Respir J. 2014;44(Suppl 58).

45. Jeong H, Hong S, Heo Y, Chun H, Kim D, Park J, et al. Vitamin D status and associated occupational factors in 
Korean wage workers: Data from the 5th Korea National Health and Nutrition Examination Survey (KNHANES 2010-2012). Ann Occup Environ Med. 2014;26(1):28, http:// dx.doi.org/10.1186/s40557-014-0028-x.

46. Romano A, Vigna L, Belluigi V, Conti DM, Barberi CE, Tomaino L, et al. Shift work and serum 25-OH vitamin D status among factory workers in Northern Italy: Cross-sectional study. Chronobiol Int. 2015;32(6):842-7, http://dx.doi.org/10. 3109/07420528.2015.1048867.

47. Tabachnick BG, Fidell LS. Using multivariate statistics. 6th ed. Boston: Pearson; 2013.

48. Emslie C, Hunt K, Macintyre S. Problematizing gender, work and health: The relationship between gender, occupational grade, working conditions and minor morbidity in fulltime bank employees. Soc Sci Med. 1999;48(1):33-48, http:// dx.doi.org/10.1016/S0277-9536(98)00287-1.

49. Hilger J, Friedel A, Herr R, Rausch T, Roos F, Wahl DA, et al. A systematic review of vitamin $\mathrm{D}$ status in populations worldwide. Br J Nutr. 2014;111(1):23-45, http://dx.doi. org/10.1017/s0007114513001840.

50. Bolland MJ, Grey AB, Ames RW, Mason BH, Horne AM, Gamble GD, et al. Determinants of vitamin D status in older men living in a subtropical climate. Osteoporos Int. 2006; 17(12):1742-8, http://dx.doi.org/10.1007/s00198-006-0190-2.

51. Lucas JA, Bolland MJ, Grey AB, Ames RW, Mason BH, Horne AM, et al. Determinants of vitamin D status in older women living in a subtropical climate. Osteoporos Int. 2005; 16(12):1641-8, http://dx.doi.org/10.1007/s00198-005-1888-2.

52. Mallah EM, Hamad MF, ElManaseer MA, Qinna NA, Idkaidek NM, Arafat TA, et al. Plasma concentrations of 25-hydroxyvitamin D among Jordanians: Effect of biological and habitual factors on vitamin D status. BMC Clin Pathol. 2011;11:8, http://dx.doi.org/10.1186/1472-6890-11-8.

53. Hyppönen E, Power C. Hypovitaminosis D in British adults at age $45 \mathrm{y}$ : Nationwide cohort study of dietary and lifestyle predictors. Am J Clin Nutr. 2007;85(3):860-8.

54. Maeda SS, Kunii IS, Hayashi L, Lazaretti-Castro M. The effect of sun exposure on 25-hydroxyvitamin D concentrations in young healthy subjects living in the city of São Paulo, Brazil. Braz J Med Biol Res. 2007;40(12):1653-9, http://dx.doi. org/10.1590/S0100-879X2006005000162.

55. Nakamura K, Kitamura K, Takachi R, Saito T, Kobayashi R, Oshiki R, et al. Impact of demographic, environmental, and lifestyle factors on vitamin D sufficiency in 9084 Japanese adults. Bone. 2015;74:10-7, http://dx.doi.org/10.1016/ j.bone.2014.12.064.

56. Grant WB. Low ultraviolet-B exposure may explain some of the link between night shift work and increased risk of prostate cancer. Int J Cancer. 2015;137(4):999, http://dx.doi. org/10.1002/ijc.29459.

57. Holick MF, Matsuoka LY, Wortsman J. Age, vitamin D, and solar ultraviolet. Lancet. 1989;2(8671):1104-5, http://dx.doi. org/10.1016/S0140-6736(89)91124-0.

58. MacLaughlin J, Holick MF. Aging decreases the capacity of human skin to produce vitamin $\mathrm{D}_{3}$. J Clin Invest. 1985;76(4):1536-8, http://dx.doi.org/10.1172/jci112134.

59. Wortsman J, Matsuoka LY, Chen TC, Lu Z, Holick MF. Decreased bioavailability of vitamin D in obesity. Am J Clin Nutr. 2000;72(3):690-3.

60. Vilarrasa N, Maravall J, Estepa A, Sanchez R, Masdevall C, Navarro MA, et al. Low 25-hydroxyvitamin D concentrations in obese women: Their clinical significance and relationship with anthropometric and body composition variables. J Endocrinol Invest. 2007;30(8):653-8, http://dx.doi.org/10.1007/ BF03347445.

61. Arunabh S, Pollack S, Yeh J, Aloia JF. Body fat content and 25-hydroxyvitamin D levels in healthy women. J Clin Endocrinol Metab. 2003;88(1):157-61, http://dx.doi.org/10.1210/ jc.2002-020978.

62. Cheng S, Massaro JM, Fox CS, Larson MG, Keyes MJ, McCabe EL, et al. Adiposity, cardiometabolic risk, and vitamin D status: The Framingham Heart Study. Diabetes. 2010;59(1):242-8, http://dx.doi.org/10.2337/db09-1011.

63. Martins D, Wolf M, Pan D, Zadshir A, Tareen N, Thadhani R, et al. Prevalence of cardiovascular risk factors and the serum levels of 25-hydroxyvitamin D in the United States: Data 
from the Third National Health and Nutrition Examination Survey. Arch Intern Med. 2007;167(11):1159-65, http:// dx.doi.org/10.1001/archinte.167.11.1159.

64. Rockell JE, Skeaff CM, Williams SM, Green TJ. Serum 25-hydroxyvitamin D concentrations of New Zealanders aged 15 years and older. Osteoporos Int. 2006;17(9):1382-9, http://dx.doi.org/10.1007/s00198-006-0118-x.

65. Palacios C, Gil K, Perez CM, Joshipura K. Determinants of vitamin D status among overweight and obese Puerto Rican adults. Ann Nutr Metab. 2012;60(1):35-43, http://dx.doi. org $/ 10.1159 / 000335282$.
66. Drincic AT, Armas LA, van Diest EE, Heaney RP. Volumetric dilution, rather than sequestration best explains the low vitamin D status of obesity. Obesity. 2012;20(7):1444-8, http://dx.doi.org/10.1038/oby.2011.404.

67. Liel Y, Ulmer E, Shary J, Hollis BW, Bell NH. Low circulating vitamin D in obesity. Calcif Tissue Int. 1988;43(4):199201, http://dx.doi.org/10.1007/BF02555135.

68. Brot C, Jorgensen NR, Sorensen OH. The influence of smoking on vitamin D status and calcium metabolism. Eur J Clin Nutr. 1999;53(12):920-6, http://dx.doi.org/10.1038/ sj.ejen.1600870.

This work is available in Open Access model and licensed under a Creative Commons Attribution-NonCommercial 3.0 Poland License - http://creativecommons.org/ licenses/by-nc/3.0/pl/deed.en. 